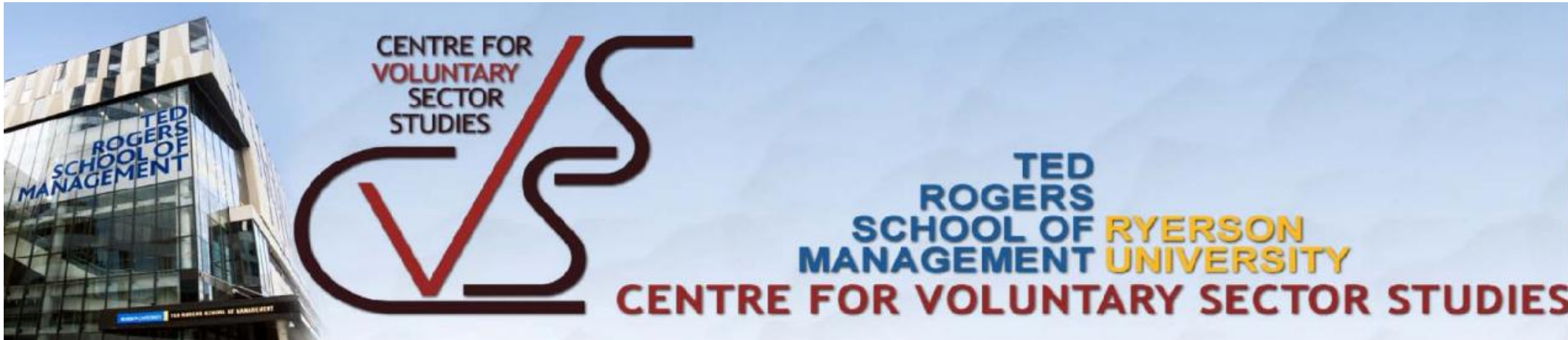

Community Service Programs in Toronto's Secondary Schools

\author{
Agnes Meinhard \\ Centre for Voluntary Sector Studies, Ryerson University \\ Mary Foster \\ Centre for Voluntary Sector Studies, Ryerson University
}

Working Paper Series

Volume 1998 (2)

350 Victoria Street,

Toronto, Ontario, M5B 2K3

Tel: (416) 979-5000 x 6739 / Fax: (416) 979-5124

cvss@ryerson.ca

http://www.ryerson.ca/cvss/working_papers/ 


\title{
Community Service Programs in Toronto's Secondary Schools ${ }^{1}$
}

\author{
Agnes Meinhard and Mary Foster \\ Centre for Voluntary Sector Studies \\ The Faculty of Business, Ryerson Polytechnic University
}

\section{Introduction}

Significant shifts have been taking place in Canada's social philosophy in the last decade or so which are having a major impact on the voluntary sector (McBride and Shields, 1997). These changes in Canada involve decreasing government participation in the provision of the social welfare net that Canadians are used to. At the same time, economic constraints are changing the nature of the partnership between government and the voluntary sector. During the post-war decades there was close cooperation between governments and the voluntary sector, with many government programs encouraging the growth of the sector through the provision of grants; today the government is down loading social services and forcing the sector to seek their funding elsewhere, while encouraging greater reliance on volunteering to provide for social services.

The sector faces a serious challenge which includes rethinking organizational strategies, such as: forging partnerships with corporations and other nonprofit organizations, marketing their organization to attract new sources of funding, restructuring their organization for greater efficiency and attracting and retaining volunteers (Foster and Meinhard, 1996). This comes after a period of significant decrease in the number of people volunteering in the decade of 1980 - 1990 (Weinrich, 1996). The idealistic, anti-establishment youth of the baby-boomer generation is being replaced by a more conservative generation of young adults who have had difficulty getting established. Having started their careers and families at a much later stage of their lives, they have neither the time nor resources to see beyond their immediate needs (Foot, 1996).

This challenge is amplified by the fact that "the nonprofit sector ... continues to face a significant problem of visibility and public awareness. So dominant has the prevailing two-sector model of social life been ... that the existence . . . of a 'third sector' of private nonprofit organizations has been largely overlooked" (Salamon and Anheier, 1996:116). Salamon and Anheier (1996:126) go on to suggest that education is the primary tool to increase awareness. Without education, "the ethos of giving will fail to develop, regardless of changes in tax and other laws."

The purpose of this study is to find out whether the schools in the City of Toronto play a role in the education process by providing structured opportunities for adolescents to volunteer and

1. This paper is dedicated to the memory of Chantal Hall Skinner, whose tireless efforts in contacting the schools in this study ensured us a very high response rate. Many thanks to Grace McDonald, who joined us in Phase 2 and organized the pretest sample and questionnaire distribution. 
serve their schools or communities. Beyond this, The study seeks to discover whether such programs enhance knowledge about and attitudes towards community and the voluntary sector, as well as students' self-esteem and tolerance of diversity. This paper will present the results of a descriptive census of community service programs in Toronto and a pretest of the instrument to be used in the before and after control group design project to be completed in June 1999.

\section{The Changing Face of Volunteer Activity}

Historically, in North America and in Britain, volunteer behaviour - the active participation in helping the poor and the needy, as opposed to merely the giving of alms - was initiated and encouraged by religious institutions and formed the foundation of the social welfare services (Feingold, 1987; de Schweinitz, 1943). By the beginning of the twentieth century, helping the poor became more secularized and professionalized as social workers gradually replaced religious volunteers. Congregational voluntary action declined (Cnaan, Kasternakis and Wineburg, 1993). The state formed a partnership with NPOs to provide the essential social services and volunteers were adjuncts to the professionals. In Canada, during the halcyon postwar years governments encouraged the formation of nonprofit social service organizations providing professional care. They were to be part of an elaborate social welfare system, allies of the state, extending specialized services that the government was uninterested in or unable to provide. Not only did these organizations receive generous funding from government sources, but more importantly they gained legitimacy to represent and serve their various constituencies (Tucker, Singh and Meinhard, 1990). However in the current political and philosophical climate of cutbacks and downloading, nonprofit organizations are in crisis, having to cut services and staff in order to survive (Foster and Meinhard, 1996; Meinhard and Foster, 1997). The contribution of volunteers is once again sought after and valued. Premier Mike Harris of Ontario, won a landslide victory on a platform that identified reliance on personal volunteering as part of his government's strategic reallocation of services in the framework of the "common sense revolution".

There is strong opposition to this emerging social philosophy. Both individuals and organizations, citing the high turnover rate and the subsequent high cost of constantly training volunteers, have presented the government with potent arguments against the devolution of social services from professionals to volunteers, (e.g., Lefebvre, 1996). Nevertheless, the reality is that government funding for social and cultural services has decreased substantially in the last few years (Barker, 1996 ). This has resulted in an attempt by social service organizations to avert cutting services by relying more on volunteers, either for help in providing services, or for fundraising purposes, where possible (Meinhard and Foster, 1997). Given the situation, these organizations may benefit from a larger and better educated pool of volunteers.

\section{Community Service Programs}

Socializing children (and members of society as a whole) to the importance of community involvement and charitable giving is a key factor in this new social philosophy. This has traditionally been a role of religious institutions, as service to others and the obligation to helping 
the poor is central to all religious teaching (Feingold, 1987). Indeed, surveys of the determinants of voluntary action among teens have consistently pointed to the importance of parental example and religious affiliation as two of the strongest factors in predicting volunteer participation (Independent Sector, 1990). Teens whose parents are volunteers and who are affiliated with organized religion in some form, are more likely to participate in volunteer activities.

In an increasingly secularized society it is unrealistic to rely solely on religious institutions to socialize societal members to community involvement and social action. As a matter of fact, Wuthnow (1991) found that religious institutions' primary goals are to encourage members first and foremost to volunteer for the benefit of the congregation. This does not necessarily translate into increased volunteer activity for the general good. Cnaan and his associates (1993), in a thorough review of studies investigating the relationship between religious beliefs and volunteering found the evidence for a relationship inconclusive. In their own study, they found no relationship between intrinsic religious motivation and volunteer activity concluding that other factors may be important in determining volunteering.

The question of why people volunteer has long intrigued researchers. Although "helping others" is the most frequently cited reason given for voluntary affiliation (Titmus, 1971; Duchesne, 1989; Carter, 1975), more probing investigations suggest that altruism represents only a minor factor (Smith, 1982; Gluck; 1975, Lang, 1986). Social catharsis (Langton, 1982), and collective identification for a "good cause" (Kramer, 1981; Duchesne, 1989) are other reasons that have been advanced. Olson (1965) suggests that affiliation can best be explained by the rational pursuit of private goods through selective incentives (i.e. tangible rewards) offered by the organization to potential members. Knoke (1986) recommends broadening the concept to include both affective incentives (eg. friendship; Flynn and Webb. 1975, Gluck, 1975) and instrumental benefits (eg. acquiring skills; Clark and Wilson, 1961; Flynn and Webb, 1975; Masi, 1981).

These findings of course do not negate a role for religious institutions in encouraging and educating their members to have greater community commitment. However, they do indicate that in order to instill voluntary community commitment and involvement in our young people, other sources of socialization are needed. The three pillars of socialization in North America are home, school and religious institution. All three of these were found to have an influence on the volunteering behaviour of teenagers (Sundeen and Raskoff, 1994). What role do schools play? A survey of American teenagers by Prudential (1995) attested to the importance of schools, parents and role models in motivating student interest in community service.

In the United States, the concept of service learning or community service in the schools dates back to the turn of the century to the writings of John Dewey who pointed to the "importance of social and not just intellectual development; and the value of actions directed towards the welfare of others" (Kraft, 1986:133). Service learning has been approached with renewed vigour in American schools in the past two decades. It is seen as an antidote to the decline in communal and civic participation witnessed over that past half century, as individualism has prevailed over community in the constant American struggle to balance the two (Barber, 1992; Bellah et al., 
1985; Putnam, 1995).

A 1986 survey of 5,400 high schools found that $27 \%$ of them had some form of community service program (Newman and Rutter, 1986). Similarly a 1990 survey of volunteering by teenagers estimated that about one quarter of American high schools offered courses which included a component of volunteering for community service (Independent Sector, 1990; Sundeen and Raskoff, 1994). In contrast to these findings, in Los Angeles County, $82 \%$ of schools, both public and private, have community service programs (Raskoff and Sundeen, 1989).

\section{Benefits of Community Service Programs}

Theoretical models of service learning suggest "that community service may promote competence and self-esteem, reduce levels of problem behaviours, provide greater knowledge of community problems and advance cognitive and moral development in adolescents" (Moore and Allen, 1996:224) In their detailed review of 8 different surveys of community service programs at both the high school and university levels, Moore and Allen (1996:242) concluded that volunteering through school programs reduced failure and dropout rates, improved reading skills, self-concept and attitudes towards society. However these programs did not relate to "increases in social competence, career exploration, greater problem solving abilities, responsibility towards school, anticipated participation in politics or beliefs in the individual's responsibility to help people in need."

Kraft (1996:143) also reviewed evaluative studies of service learning programs. He concluded that there is "a lack of solid evidence on the effects of these programs" because it is "difficult to isolate the effects of service on specific academic achievements." He categorized the effects of service learning programs into five areas of impact:

a) social growth - the findings are mixed, some evidence that students become more service oriented, less prejudiced, more democratic, greater sense of social responsibility

b) psychological development - there is evidence that service learning programs have a positive effect on the development of a positive self-image, increased self-confidence and self-esteem.

c) moral judgment - the results are mixed, but there is some evidence of impact on moral judgment

d) academic learning - again there are mixed results. In general tests of knowledge there is usually no difference between service learners and the control groups, but on measures of reading and math achievement scores of tutors, there is improvement.

e) community served - there is evidence that young people have a positive impact on the community.

Presently in the United States, where there is a major federally funded effort underway called "Learn and Serve America School and Community-Based Programs". The program was established in 1993 with the objective of involving "school aged youth in programs and classroom activities that link meaningful service in the community with a structured learning experience" 
(Melchior, 1997:1). "Service-learning stands in contrast to traditional voluntarism... (in that it includes)... reflection and links to organized curriculum" (Melchoir, 1997:11).

Approximately $\$ 30$ million in grants were awarded, in the first year of the program, to support 2000 local efforts involving more than 750,000 school-aged youth. The Center for Human Resources at Brandeis University is conducting a long-term evaluation of the impact of the program. In their initial article they reported statistically significant impacts on measures of personal and social responsibility, acceptance of cultural diversity and service leadership, with program participants scoring higher on all of these measures than nonparticipants. Program participants also volunteered their services more frequently and for longer hours. Interestingly the grade point averages, as well as other educational measures, showed greater improvement for participants than for nonparticipants (Melchior, 1997).

\section{Community Service in Canada}

The tension between individual pursuit of happiness and the good of the community that many scholars have remarked upon in the United States (Barber, 1992; Bellah et al., 1985, Putnam, 1995), is not a characteristic feature of Canada. As opposed to every individual's right to "Life, Liberty and the Pursuit of Happiness," as stated in the Declaration of Independence, the preamble of Canada's Constitution Act, 1867, talks of "Peace, Order and Good Government". It wasn't until the patriation of the constitution in 1982, that Canada had a written Charter of Rights outlining individual rights and obligations. For many historical reasons, in Canada, the common good generally took precedence over individual rights. In the struggle to keep the wide expanse of Canada together, Canadian government was always more involved in the management of both the economy and the welfare of its citizens. Thus the partnership between the voluntary sector and the government took a different form in Canada from that in the U.S. (Shields and Evans, 1998). In fact, there is a widely held opinion that there really is no "third" sector in Canada, as voluntary social service organizations are viewed as part of the public sector because of the symbiotic nature of the relationship. It is the obligation of governments at all levels to support social services provided by professionals, regardless of the delivery mode, i.e. whether through a branch of government or through a government funded social service agency. This philosophy is only now beginning to unravel in the "name of fiscal restraint and the new competitive global order" (Shields and Evans, 1998:17). The deep-seated belief in a strong state role in society has been undermined, and has significantly changed the environment in which voluntary social service agencies must exist.

There have been no country wide initiatives in Canada such as the "Learn and Serve America" program, nor have there been the kind of nation-wide calls for the inclusion of community service programs in schools as issued in the U.S. by Goodlad (1984) and Boyer (1983) and the Carnegie Task force on Education of Young Adolescents (1989). However recently, Ontario's Minister of Education, announced that in order to graduate, Ontario high school students would have to "volunteer" 40 hours of their time in compulsory community service activities (Globe and Mail, January 10, 1998). A similar program is underway in British Columbia. Currently, not much is 
known about the extent of volunteer community service programs across Canada or in the individual provinces. The objective of the first phase of this study was to take a measure of the extent of community service programs in Toronto's secondary schools.

\section{Method for Descriptive Census}

Sample: At the time of the survey, Metropolitan Toronto was divided into 6 school districts. We ascertained the names and telephone numbers of every high school - public, Catholic (separate) and independent - in each of the districts. The listings for public and Catholic schools were found under the different school districts in the telephone book. Listings for the independent schools were from a publication, put out by the Ministry of Education and Training, of approved independent schools. In all 120 public, 40 Catholic and 30 independent schools were contacted. One hundred and sixty-two of the 190 schools we contacted responded to our survey, for an overall response rate of eighty-five percent: $83 \%$ of public schools, $88 \%$ of Catholic schools and $90 \%$ of independent schools.

Survey instrument: A structured questionnaire was used for the telephone interviews. The initial question asked whether the school had a volunteer service program. If the answer was no, the respondent was asked if the school had ever had one, and if they were considering one in the future. Those schools which had service programs were asked about the programs: Length of time the program was in place, grades involved, whether the program was mandatory, how many hours of service was required, number of students participating, number of staff members involved, how students find their placements, how records are kept, whether the school has evaluated their program. All respondents were asked school demographics: number of students, number of staff, whether the school was coed or not.

\section{Results of Descriptive Census}

Background: In the City of Toronto there are three different school systems. First, there are public schools which are managed by the Public Board of Education, are supported by tax dollars and which any resident of school age has a right to attend. The separate system encompasses the Catholic schools and is managed by the Catholic Board of Education. While it has always been supported by tax dollars, it is only within the last decade that the tax support for the public and separate systems has been equalized. In order to have their children attend separate schools, taxpayers must indicate on their enumeration form that they want their taxes to be paid to the separate system. By default they are paid to the public system. The third system includes all the independent schools and is funded privately through tuition fees.

The public school system in Toronto offers programs at a range of academic levels including special programs for learning disabled and gifted children. Both developmentally and physically challenged students are integrated into mainstream classes whenever possible. Because of the high immigrant population, many schools also have active ESL programs (English as a second language). 
In most separate schools, students wear uniforms and must conform to a code of conduct. Religious education is included in the curriculum. They also have programs for students with special needs, but to a lesser extent than the public schools because of historical underfunding to the system.

Most independent schools are based on competitive academic entry although some are set up with a religious affiliation or specific educational philosophy. Most students wear uniforms and participation in extra-curricular activities is the rule rather than the exception. Yearly tuition fees range from $\$ 8,000$ to $\$ 15,000$ for day students and about $\$ 30,000$ for boarders.

Findings: One hundred and sixty-two schools responded to the telephone survey: 99 public schools $(61 \%$ of the sample, 35 separate schools $(22 \%)$ and 28 private schools $(17 \%)$. In all, 74 (46\%) have volunteer community service programs of some sort. The Catholic School Board had the highest proportion of schools with volunteer programs: $71 \%$ ( 25 schools). Forty-three percent of the independent schools (12 schools) and 37\% of the public schools ( 37 schools) have volunteer community service programs. The difference among the three systems is significantly different $($ Chi-Square $=12.38, \mathrm{p}=.002)$

In $40 \%$ of the schools the program is mandatory. Here again there are significant differences (Chi-Square $=5.78, \mathrm{p}=.055$ ) among the schools systems with $43 \%$ of the public schools having mandatory programs, $50 \%$ of the Catholic schools and $7 \%$ of the independent schools.

Although the community service program is offered in all grades, it is more likely to be offered in grades 11 through 13. Thirty percent of schools have programs in these grades as opposed to $22 \%$ offering such programs in the lower grades. Just over one-third of all schools offer the program only in one grade, while another third offer the program in all grades 9 through 13.

The number of students participating in the program range from 2 students in one school to 1300 students in another. The median number of students participating in the program in each school is 59. The ratio of participants to the total student body is on average $10 \%$. In five schools the entire student body participates.

In schools where the program is optional, students volunteer for an average of 34 hours a semester. In schools where the program is mandatory, the average number of volunteer hours is 12 per semester. Approximately one-third (32\%) of the schools have only one staff member involved in the program, and $37 \%$ have 2 to 3 staff members involved. The remaining $31 \%$ have from 4 to 70 staff members involved in some way in the program.

On average the program has been in place for 7 (median 6) years, but the range is from 1 year to over 50 years. Sixteen percent have had the program for only one year. The 11 eleven private schools have a longer track record of participation in community service programming with the average being 12 (median 10) years. 
Of the 86 schools that do not have a community service program, only $15(17 \%)$ indicated that they are considering one in the future.

\section{Discussion of Descriptive Census Results}

This survey indicates that there is a good start in Toronto schools to give students some hands on experience in volunteering time to serve their communities. The large number of schools reporting that they have only had the program for one year indicates a growing awareness among educators of the importance of community. There is no clear policy however, at the level of the school boards. The programs are at the discretion of the individual schools and often they are just the result of the efforts of a single teacher in a single class.

The Toronto study findings have some similarities and some differences with another large study being conducted by Raskoff and Sundeen $(1997,1998)$ in California. In the first phase of the California study they surveyed all public and independent schools (religious and non-sectarian) in Los Angeles County and found that a clear majority of the schools $(82 \%)$ provided some kind of community service program. This is a much higher level of participation than was found in the Toronto schools (46\%). On the other hand, the Toronto level is higher than the $27 \%$ found in the study by Newman and Rutter (1986), and the 25\% participation rate found in the 1990 study by the Independent Sector. It is not clear whether the participation level discrepancies are influenced by differences in the school system, differences in the student population, differences in the measurement instruments or differences in the program itself.

The higher participation rate in Toronto's Catholic Schools (71\%) is similar to the California findings. Raskoff and Sundeen found that, although all three types of schools had high participation rates, the religious schools scored the highest $(87 \%)$, followed by the public schools $(81 \%)$ and finally the non-sectarian independent ones $(77 \%)$. However, in terms of proportion of students participating, the non-sectarian independent schools had the highest rate $(80 \%)$, followed by the religious (73\%) and far behind these two the public schools $(31 \%)$. They suggest that this is a reflection of the "difficult logistic problems of providing and monitoring service opportunities in large public schools (Raskoff and Sundeen, 1998:75).

The second phase of the study was to test the instrument to be used in the before and after, experimental/control group design.

\section{Method for Pretest}

Sample: Twelve schools from the 162 census respondents were contacted. Nine agreed to participate in the pretest of the survey instrument including 4 separate schools in which the community service program was mandatory, 3 public schools in which the program was voluntary and 2 private schools which had a mixture of mandatory and voluntary.

Survey Instrument: We obtained permission from the researchers at Brandeis University to adapt 
or administer as is, the instrument that was used in the Learn and Serve America evaluation. It was based on existing attitudinal scales and questionnaires that were being used in studies of similar programs. Included are scales measuring service experience, educational competence, personal and social responsibility, acceptance of diversity, communication skills, work orientation, engagement in service learning, leadership, formal helping behaviour and self-esteem.

Students completed the questionnaire in a classroom setting with a member of the research team supervising. Students were advised that the survey was confidential and that only the researchers would have access to the completed questionnaires. Part of the pretest was to determine the length of time required for administering the questionnaire. Unfortunately, some of the schools had only allocated 20 minutes to complete the survey, when 30 minutes was needed. As a result of this time constraint, there are missing values on some questions.

A small control group was included in the study design, but with only 13 respondents it was impossible to use the data collected for any meaningful analysis.

\section{Results of Pretest}

There were no significant differences among the 233 respondents when grouped by school system on satisfaction with the community service experience.

About half (47\%) report being very satisfied with the overall experience and $40 \%$ somewhat satisfied. Thirty-six percent felt the service was very helpful to the community and $49 \%$ felt it was somewhat helpful. Fifty-four percent felt the program was very helpful to the individuals being served.

Respondents also saw personal benefits in that $68 \%$ report learning a skill through the experience that will be helpful in the future.

While $88 \%$ felt student should be encouraged to participate, $40 \%$ felt student participation in community service programs should be mandatory.

Thirty-five percent of participants worked in a team in their community service program, $17 \%$ worked on their own, and the rest did both.

The majority (65\%) worked in a human services capacity, for example taking care of children, helping the elderly or working in a hospital, a homeless shelter or a food bank. Thirty-seven percent worked in education as a teacher's aide, mentor, tutor or helping with school clean-up.

The majority (65\%) worked in activities that directly helped other people, whereas $22 \%$ were involved in activities such as fund raising or collecting food that indirectly help others.

Forty-seven percent designed or selected their specific volunteer service project while $42 \%$ were 
assigned an activity by someone else.

In $39 \%$ of the cases, the participants kept a journal or diary as part of their project, and for $35 \%$ a specific time was set aside in class to discuss service experiences.

Students report other benefits to participating in community service programs. More than half (52\%) report learning more through their voluntary service project than they learned in a typical class. About 30\% feel the experience helped them think of the kind of job they might want. Similarly, 33\% feel they learned more about a career in which they might be interested.

Interestingly, 57\% report having done additional volunteering outside of the community service program in the school.

\section{Discussion of Pretest Results}

Without a valid control group, it would be misleading to discuss the relationship between participating in a community service program and the attitudinal or behavioural outcomes. The purpose of this step in the project was to test the suitability of the Brandeis instrument for the Toronto student population.

Some of the results in the pre-test appear to reflect the differences in the student populations in each of the school systems. For example, on six of the ten items in the communication skills index the independent school respondents scored significantly higher than their public or separate school counterparts.

In addition, some of the results reflect the unique characteristics of Toronto. Toronto is Canada's largest city with 2.4 million residents in the city proper. However, the Greater Toronto Area (GTA) has a population of 4.7 million (Toronto Star, Nov. 13, 1997, Final Edition, p.C2). It is the financial and corporate capital of Canada and because of its multi-ethnic character it is the city of choice for most new immigrants. The last census listed 24 major ethnic groups in Toronto and many other minor ones (Toronto Star, February 18, 1998, Final Edition, p.A1). Chinese has now passed Italian as the second largest language in Toronto. Punjabi, Arabic, Tagalog, Spanish, Tamil, Vietnamese, Persian, Russian, Polish, Urdu and Hindi have all seen major increases in the past five years (Toronto Star, January 4, 1998, Final Edition, p.F6).

This background is important because the multicultural character of Toronto has a decided influence on the attitudes toward diversity among high school respondents. On a 4 point scale where the higher the number the more accepting of diversity, regardless of school system, the average scores for both the index and the individual items were between 3.2 and 3.7. Although there is no control group to compare with, it seems a reasonable assumption that the ethnic diversity already present in the city has fostered a level of tolerance that will be influenced minimally if at all by participation in a community service program. 


\section{Conclusion}

A key finding from the pretest is that the uniqueness of the Toronto population may have an impact on the scale scores of the various indices. The Brandeis researchers incorporated existing attitudinal scales into their instrument and were satisfied with the reliability and validity of the results. Given some of the pretest results, it seems clear that these scales will have to be renormed for the Toronto population. Indeed, if we expand this study across the province or nationwide, the items will once again have to be re-normed as Toronto is not at all representative of either Ontario or Canada in terms of ethnic distribution

\section{References}

Baker, J. (1996). Personal Communication, Metro Toronto Social Planning Council.

Barber, B. (1992). An Aristocracy of Everyone. New York: Ballantine.

Bellah, R., Madsen, R., Sullivan, W., Swidler, A. \& Tipton, S. (1985). Habits of the Heart. Berkeley: University of California Press.

Boyer, E. (1983). High School. New York: Harper and Row.

Carnegie Task Force on Education of young Adolescents. (1989). Turning Points: Preparing American youth for the 21st century. New York: Carnegie Council on Adolescent Development of the Carnegie Corporation.

Cnaan, R., Kasternakis, A. \& Wineburg, R.J. (1993). Religious people, religious congregations, and volunteerism in human services: Is there a link? Nonprofit and Voluntary Sector Quarterly, $22(1): 33-51$.

de Schweinitz, K. (1943). England's Road to Social Security. New York: Barnes.

Feingold, Mordechai (1987). Philanthropy, pomp and patronage: Historical reflections upon the endowment of culture. Daedalus, 116 (1): 155-178.

Foot, D.K. (1996). Boom, Bust and Echo. Toronto: McFarlane, Walter and Ross.

Foster, M.\& Meinhard, A. (1996). Toward Transforming Social Service Organizations in Ontario. Presented at Babson Conference on Entrepreneurship, Seattle, WA.

Globe and Mail. (1998) January 10, page 1.

Goodlad, J. (1984) A Place Called School. New York: McGraw-Hill. 
Independent Sector. (1990). Volunteering and Giving Among American Teenagers 14 to 17 Years of Age: Findings from a National Survey. Independent Sector, Washington, DC.

Kraft, Richard (1996). Service learning: An introduction to its theory, practice and effects. Education and Urban Society, 28 (2): 131-159.

Lefebvre, B. (1996). From minutes of the Standing Committee on General Government, Government of Ontario. Timmins Ont.: June 16, 1996.

McBride, S. \& Shields, J. (1997). Dismantling a Nation: The Transition to Corporate Rule in Canada. Halifax: Fernwood Publishing.

Meinhard, A.\& Foster, M. (1997). Responses of Women's Voluntary Organizations to the Changing Social, Political and Economic Environment. Presented at the 26th Annual ARNOVA Conference, Indianapolis, IN.

Melchior, A. (1997). National Evaluation of Learn and Serve America School and CommunityBased Programs: Interim Report. Unpublished Manuscript.

Moore, C.W. \& Allen, J.P. (1996). The effects of volunteering on the young volunteer. The Journal of Primary Prevention, 17 (2): 231-258.

Newman, F.M. \& Rutter, R.A. (1986). Profile of high school community service programs. Educational Leadership, 43 (4): 65-71.

Prudential. (1995). Prudential Spirit of Community Initiative: Highlights of the Youth Survey of Community Involvement.[Online] http://www.prudential.com/community/spirit/cmszz1004.html

Putnam, R.D. (1995). Bowling alone: America's declining social capital. Journal of Democracy, 6 (1): $65-78$.

Salamon, Lester M. \& Anheier, Helmut K. (1996). The Emerging Nonprofit Sector: An Overview. Manchester: Manchester University Press.

Shields, J. and Evans, M.B. (1998). Shrinking the State: Globalization and Administration "Reform". Halifax: Fernwood Publications

Sundeen, R. \& Raskoff, S. (1994). Volunteering among teenagers in the United States. Nonprofit and Voluntary Sector Quarterly, 23 (4):383-403.

Toronto Star. (1997) November 13, Final Edition: C2.

Toronto Star. (1998) January 4, Final Edition: F6. 
Toronto Star. (1998) February 18, Final Edition: A1.

Tucker, D.J., Singh, J.V. and Meinhard, A.G. (1990). Organizational form, population dynamics and institutional change: A study of birth patterns of voluntary organizations. Academy of

Management Journal, 33:151-178.

Weinrich, P. (1996). The Third Sector. http://www.volunteer.ca/3rdsectr.htm

Wuthnow, R. (1991). Acts of Compassion: Caring for Others and Helping Ourselves. Princeton, NJ: Princeton University Press. 